\title{
Effect of Different Postharvest Treatments on Prolonging Shelf life of Citrus reticulata Blanco.
}

\author{
Pabitra Joshi ${ }^{1}$, Bishnu Raj Ojha ${ }^{1}$ and Arun Kafle ${ }^{2}$ \\ ${ }^{1}$ Agriculture and Forestry University, Rampur, Chitwan, \\ ${ }^{2}$ Vegetable Crops Development Centre, Khumaltar, Lalitpur \\ Corresponding author's email address: pabitrajoshi77@gmail.com
}

Received on: 16 July 2019, Revised on: 10 November 2019, Accepted on: 5 December 2019

\begin{abstract}
This study was conducted during January to April 2018 to evaluate the effect of different post-harvest treatments on maintaining quality and shelf life of mandarin. Laboratory experiment was conducted under Complete Randomized Design (CRD) with four replications and seven treatments (T1 = Control i.e. dipped in distilled water, T2 = Cinnamon oil@2\%, T3= Eucalyptus oil@2\%, T4=Calcium chloride @1\%, T5= Bavistin@0.1\%, T6 = Paraffin Wax@10\%, T7 = Paraffin Wax@10\%+ Bavistin@0.1\%). Data were recorded in every 2 days interval and the final data was taken in 13 days interval because of the limited destructive sample. Postharvest treatment with wax @10\% in combination with Bavistin@0.1\% had minimum physiological loss in weight (6.61\%) and maximum juice recovery percentage (43.72\%) which was statistically at par with wax (10\%), Bavistin $(0.1 \%)$, Cinnamon oil (2\%), Eucalyptus oil (2\%) and Calcium chloride (1\%) treated fruits. Also at the end of storage period the highest Total soluble solute (TSS) content $\left(15.45^{\circ}\right.$ Brix) was recorded in Calcium chloride $(1 \%)$ treated fruits which were statistically at par with control, Eucalyptus oil $(2 \%)$, Bavistin (0.1\%) treated fruits. The $\mathrm{pH}$ was found non-significant throughout the storage period whereas postharvest life was found the maximum (73 Days) in fruits treated with wax (10\%) in combination with Bavistin (0.1\%) while it was only 46 days in control.
\end{abstract}

Keywords: Acidity, Ascorbic acid, Carotenoids, Lycopene, Dehydration ratio

\section{Introduction}

Mandarin (Citrus reticulata Blanco.) is a group name for a class of oranges belonging to family Rutaceae with bright colored peel and pulp, excellent flavor, easy-topeel rind and segments that separate easily, is believed to have originated in Southeastern Asia (Parashar, 2009). In Nepal, the total area production and productivity of mandarin orange is 16,248 hectare, 146,690 Metric tons and $9.0 \mathrm{Mt} /$ ha which is very low compared to the most citrus growing countries in the world (MoAD, 2016). Low productivity, decline in quality and heavy postharvest losses are key hurdles faced by Nepalese fruit industry (Rokaya, 2017).
Nearly 20-25 percent of mandarin fruits are wasted due to faulty postharvest management i.e. $7 \%$ during harvesting, $25 \%$ during transportation, $3 \%$ while grading, $10 \%$ in packaging, and 5\% during marketing (Bhattarai et al. 2013). Since fruits are perishable in nature they cannot be kept for a long-time during transportation and storage. Due to low adaptation of improved techniques during pre and post-harvest stage, both external and internal chemical quality attributes are lost. The postharvest losses can be minimized by extending shelf life through checking the rate of transpiration, respiration, microbial infection \& protecting membranes from disorganization (Sahu, 2016). Among the different methods used to extend the shelf life alternative of low-cost technology i.e. the

Copyright (C) 2020 Nepal Horticulture Society. This article is licensed under Creative Commons Attribution 4.0 International License. This permits unrestricted use, distribution and reproduction in any medium provided the original work is properly cited. 
application of the edible coating (oil, wax, chemical) to fruit has received attention worldwide as these coatings are maintaining quality even under ordinary storage condition (Bisen et al. 2012). Edible coating of fruits can result in the creation of a modified atmosphere due to blockage of the pores within the fruits, reducing respiration rate and improving postharvest quality (Kader, 2005). Considering the above facts this study was carried out with the general objective of evaluating the effect of different postharvest treatments on fruit quality and shelf life of mandarin under room condition.

\section{Methodology}

Mandarin fruit of Khoku Local cultivar (local mandarin of Dhankuta) with uniform size, healthy, greenish yellow and well matured from the private orchard of Udayapur district (Katari Municipality, Katunje, one of the potential districts for mandarin cultivation in Nepal) were selected and harvested by clipper keeping with small pedicel intact and collected in crates from the orchard on Poush 25, 2074 (January 09, 2018). The collected fruits were sorted and graded on the basis of size (uniform medium sized) and maturity (greenish yellow in color) for treatments. The fruits were stored under an ambient condition at Beteni lab (PMAMP Citrus Zone) which is located 1300 masl at Udayapur District, Nepal. The experiment was conducted from January to April, 2018 which was laid out in CRD with 7 treatments each replicated 4 times. The treatments applied were T1: Control (distilled water), T2: Cinnamon oil@2\%, T3: Eucalyptus oil @2\%, T4: Calcium Chloride (CaCl2)@1\%, T5: Bavistin $@ 0.1 \%$, T6: Wax emulsion @10\%, T7: Wax (10\%) in combination with Bavistin (0.1\%). Different Essential oils (Cinnamon oil, Eucalyptus oil) at $2 \%$ concentration was prepared. The fungicidal solution of Bavistin

\section{Titrable acidity (TA)}

The acidity of the fruits from each treatment was estimated as per standard procedures of AOAC (2005). A total of $10 \mathrm{ml}$ of the clear juice of a fruit from each
@ $0.1 \%$ was prepared by dissolving $1 \mathrm{~g}$ of Bavistin (amorphous) $1000 \mathrm{ml}$ of distilled water. This emulsifier wax solution was prepared as a procedure outlined by (Rokaya, 2017). Fruits from each treatment separately dipped for 2 minutes in each prepared solution in a bucket and were dried for 5 minutes under the shed over the newspaper. After the treatment completion, 10 fruits from each treatment were allocated in the plastic tray as a destructive sample from which every time one fruit per replication was used for analysis and 5 fruits of each treatment were allocated in each tray as the non-destructive sample under the ambient condition $12.42 \pm 0.280 \mathrm{C}$ mean temperature, $68.56 \pm 1.46 \% \mathrm{RH}$ for 41days where temperature and $\mathrm{RH}$ was measured with the help of digital thermo-hygrometer (ERMA) three times a day and was averaged for the whole duration. Observations were recorded in 2 days interval up to 27days and final observation was taken at 41 day (because of limited sample). Following parameters were evaluated during the storage period.

\section{Physiological Loss in weight (\%)}

Weight loss was recorded in the same 5 fruits (nondestructive sample). A digital sensitive balance was used to determine fruit weight. The weight loss was calculated according to the formula:

$\mathrm{W} 1=[(\mathrm{W} 0-\mathrm{Wt}) / \mathrm{W} 0] \times 100 \%$

Where $\mathrm{W} 1$ is the percentage weight loss,

W0 is the weight of the initial fruit and

$\mathrm{Wt}$ is the weight of the fruits at the designated time.

\section{Total Soluble Solid (0Brix)}

Total soluble solids (0Brix) was determined with the help of Erma hand-held refractometer.

treatment was taken and titrated against standard $0.1 \mathrm{~N}$ of sodium hydroxide $(\mathrm{NaOH})$ solution using phenolphthalein as an indicator. Then the titrable acidity of the fruit was expressed in percentage using the following formula:

$$
\text { Titrable Acidity }(\%)=\frac{\mathrm{ml} \text { of } \mathrm{NaOH} \text { used } \mathrm{x} \text { acid factor }(\text { i.e } 0.0064 \text { for citric acid) } \mathrm{x} 100}{\text { Volume }(\mathrm{ml}) \text { of Juice used }}
$$

\section{TSS/TA}

TSS /TA ratio was calculated by dividing the TSS content by titrable acidity of each treatment and average was recorded. Following formula was used to calculate TSS/TA ratio:

$$
\text { TSS } / \mathrm{TA}=\quad \frac{\text { Total soluble solids }}{\text { Titrable acidity }}
$$




\section{pH of the juice}

$\mathrm{pH}$ of the juice was measured with the help of digital $\mathrm{pH}$ meter.

\section{Temperature \& RH}

Temperature and $\mathrm{RH}$ were recorded each day during the experimental period using ERMA thermo-hygrometer.

\section{Juice content}

Juice was extracted by squeezing by hands. The volume of juice was measured (ml/fruit) using beaker. Average juice percentage per fruit was obtained from the following formula:

Juice $(\%)=\frac{\text { Juice weight per fruit } \times 100}{\text { Individual fruit weight }}$

\section{Statistical method}

The data pertaining to various parameters were collected at different stages and intervals and tabulated in an Excel sheet for analysis as mentioned by Gomez and Gomez (1984). All routine statistical analysis was carried out using Genstat software 15th Edition. This software was used to generate (LSD) test at $0.05(\mathrm{p}<=0.05)$ by Analysis of Variance (ANOVA) to determine the significant difference among the treatment means.

\section{Results and Discussions}

\section{Physiological loss in weight (PLW)}

The physiological loss in weight(PLW) was significantly increased in all the treatments with the advancement of the storage period and the increasing trend in the weight loss percentage was found the maximum in control up to 41 days of storage. Minimum percentage of PLW was observed in the fruits treated with wax in combination with Bavistin during the whole storage period and the losses ranged from $0.90 \%$ in 6 th day to $6.61 \%$ in 41 th day whereas maximum weight loss was recorded in the fruits with untreated as control $(1.59 \%$ to $18.09 \%)$ which was statistically at par with the findings of Calcium chloride (1\%), Eucalyptus oil $(2 \%)$ and Bavistin $(0.1 \%)$ during the storage (Table 1$)$.

This minimum weight loss in the wax-treated fruits was might be due to retardation in the process of transpiration and respiration by the closing of lenticels and stomata of the cell wall of the fruit skin. Thus wax emulsion might have been an effective treatment to reduce weight loss. Wax coated fruits retained better glossiness and fresh appearance being a moisture barrier in the study carried by (Mahajan et al. 2005). A study in tangerine citrus var. Siam Banjar showed that the application of wax coatings in combination with low-temperature storage proved effective in reducing the percentage weight loss (Hassan et al. 2014). The findings were in consonance with the findings of the Ahmad et al. (2013) in Kinnow fruit, Rokaya (2017) in Mandarin, Sahu (2016) in custard apple, who found minimum weight loss in the fruits treated with a wax emulsion.

Table 1: Effect of postharvest treatments on physiological weight loss (\%) of mandarin fruit during storage at ambient condition $(12.42 \pm 0.280 \mathrm{C}$ mean temperature, $68.56 \pm 1.46 \% \mathrm{RH})$, Udayapur, Nepal, (2017-18)

\begin{tabular}{|l|l|l|l|l|l|l|l|l|l|l|}
\hline \multirow{2}{*}{ Treatments } & \multicolumn{9}{l|}{ The physiological loss in weight (\%) on days indicated } \\
\cline { 2 - 11 } & 6DAY & 9DAY & 12DAY & 15DAY & 18DAY & 21DAY & 24DAY & 27DAY & 30DAY & 41DAY \\
\hline Control & $1.59 \mathrm{abc}$ & $3.81 \mathrm{a}$ & $6.03 \mathrm{a}$ & $6.98 \mathrm{a}$ & $8.25 \mathrm{a}$ & $9.21 \mathrm{a}$ & $10.79 \mathrm{a}$ & $12.06 \mathrm{a}$ & $14.29 \mathrm{ab}$ & $18.09 \mathrm{a}$ \\
\hline Cinnamon Oil (2\%) & $1.25 \mathrm{bcd}$ & $2.19 \mathrm{~b}$ & $4.70 \mathrm{bc}$ & $5.95 \mathrm{ab}$ & $6.89 \mathrm{ab}$ & $7.52 \mathrm{ab}$ & $9.09 \mathrm{ab}$ & $9.71 \mathrm{bc}$ & $10.28 \mathrm{c}$ & $12.70 \mathrm{~b}$ \\
\hline Eucalyptus oil (2\%) & $1.56 \mathrm{abc}$ & $2.81 \mathrm{ab}$ & $4.06 \mathrm{c}$ & $5.01 \mathrm{~b}$ & $5.94 \mathrm{~b}$ & $6.88 \mathrm{~b}$ & $7.82 \mathrm{~b}$ & $9.07 \mathrm{c}$ & $12.20 \mathrm{bc}$ & $14.38 \mathrm{ab}$ \\
\hline CaCl2 (1\%) & $2.17 \mathrm{ab}$ & $3.41 \mathrm{a}$ & $6.19 \mathrm{a}$ & $6.81 \mathrm{a}$ & $7.74 \mathrm{a}$ & $8.67 \mathrm{ab}$ & $10.22 \mathrm{a}$ & $11.15 \mathrm{ab}$ & $15.17 \mathrm{a}$ & $17.03 \mathrm{a}$ \\
\hline Bavistin $(0.1 \%)$ & $2.23 \mathrm{a}$ & $3.51 \mathrm{a}$ & $5.73 \mathrm{ab}$ & $6.05 \mathrm{ab}$ & $7.32 \mathrm{ab}$ & $8.28 \mathrm{ab}$ & $10.51 \mathrm{a}$ & $11.47 \mathrm{ab}$ & $14.97 \mathrm{a}$ & $17.83 \mathrm{a}$ \\
\hline Wax $(10 \%)$ & $0.60 \mathrm{~d}$ & $0.90 \mathrm{c}$ & $2.09 \mathrm{~d}$ & $2.09 \mathrm{c}$ & $2.40 \mathrm{c}$ & $2.99 \mathrm{c}$ & $3.89 \mathrm{c}$ & $4.19 \mathrm{~d}$ & $6.58 \mathrm{~d}$ & $11.98 \mathrm{~b}$ \\
\hline $\begin{array}{l}\text { Wax }(10 \%) \\
\text { Bavistin }(0.1 \%)\end{array}$ & $0.90 \mathrm{~cd}$ & $1.20 \mathrm{c}$ & $1.80 \mathrm{~d}$ & $2.10 \mathrm{c}$ & $3.01 \mathrm{c}$ & $3.01 \mathrm{c}$ & $3.91 \mathrm{c}$ & $3.91 \mathrm{~d}$ & $5.41 \mathrm{~d}$ & $6.61 \mathrm{c}$ \\
\hline SEm $( \pm)$ & & & & & & & & & & \\
\hline LSD $(=0.05)$ & 0.293 & 0.293 & 0.326 & 0.354 & 0.532 & 0.458 & 0.592 & 0.539 & 0.759 & 1.227 \\
\hline CV, \% & 39.8 & 25.6 & 16.2 & 21.3 & 15.4 & 17.8 & 13.4 & 13.3 & 13.5 & 17.4 \\
\hline P-value & 0.005 & $<0.001$ & $<0.001$ & $<0.001$ & $<0.001$ & $<0.001$ & $<0.001$ & $<0.001$ & $<0.001$ & $<0.001$ \\
\hline Grand mean & 1.47 & 2.55 & 4.37 & 5.00 & 5.94 & 6.65 & 8.03 & 8.79 & 11.27 & 14.09 \\
\hline
\end{tabular}

LSD = Least Significant Difference, $\mathrm{SEM}=$ Standard Error of Mean, and CV $=$ Coefficient of variation, $\mathrm{ns}=\mathrm{non}-$ significant 


\section{Juice content}

Table 2 shows that the juice recovery percentage was decreased with time during the storage in all the treatments but was not significantly lower. Wax + Bavistin treated fruits recorded the maximum juice recovery percentage $(43.72 \%)$ which was statistically at par with the findings of Wax $10 \%$, Bavistin $0.1 \%$, Eucalyptus oil (2\%), Cinnamon oil (2\%) and Calcium chloride $1 \%$ at 4 th day of storage whereas the minimum juice recovery percentage $(33.89 \%)$ was observed in control fruits.

The trend of decrease in juice percentage during the storage was might be due to loss of moisture from the surface of the fruits. The wax treated fruits in combination with Bavistin showed a low reduction in juice content during storage as compared to control or other essential oils. This might be due to the fact that the wax acted as a barrier which had checked the losses of the moisture from the fruit surface. Ahamad et al. (2013) reported higher juice recovery percentage in PE-packed (Polyethylene packed) fruits (T10) followed by the fruits with 100\% Sta-Fresh 960 (T4) (Trade name of a commercial edible coating material) which might be due to less water loss in PE-packaging and waxing treatments as the combination acts as a barrier to moisture loss. The minimum decrease in juice percentage was observed in the fruits treated with wax $10 \%$ plus Bavistin $0.1 \%$ from the 1 st week (49.56\%) to the 4 th week (43.81\%) followed by wax $10 \%$ from the 1 st week $(49.49 \%)$ to the 4 th week $(43.45 \%)$ as against control from the 1st week (47.26\%) to the 4th week (34.65\%). Rokaya (2017) reported that the fruits treated with wax and in combination with Bavistin showed low reduction in juice content during storage as compared to other chemically treated fruits and control which might be due the fact that the wax acted as a barrier which had checked the losses of the moisture from the fruit surface. These results are in line with Mahajan et al. (2013) in Kinnow fruit, Bisen et al. (2012) in Kagzi lime.

Table 2: Effect of postharvest treatments on juice recovery (\%) of mandarin fruit during storage at ambient condition (12.42 $\pm 0.280 \mathrm{C}$ mean temperature, $68.56 \pm 1.46 \% \mathrm{RH})$, Udayapur, Nepal, (2017-18)

\begin{tabular}{|l|l|l|l|l|l|l|l|l|l|l|}
\hline \multirow{2}{*}{ Treatments } & \multicolumn{9}{|l|}{ Juice recovery \% of fruit on days indicated } \\
\cline { 2 - 12 } & Day 3 & Day 6 & Day 9 & Day 12 & Day 15 & Day 18 & Day 21 & Day 24 & Day 27 & Day 41 \\
\hline Control & 46.60 & 45.89 & 44.61 & 44.26 & 43.72 & 42.27 & 41.02 & 39.82 & 38.00 & $33.89 \mathrm{~b}$ \\
\hline Cinnamon Oil (2\%) & 46.81 & 46.47 & 46.33 & 44.60 & 44.56 & 43.83 & 42.43 & 41.52 & 40.61 & $37.07 \mathrm{ab}$ \\
\hline Eucalyptus oil (2\%) & 48.23 & 47.67 & 47.64 & 46.95 & 45.70 & 45.50 & 44.81 & 44.80 & 38.62 & $37.80 \mathrm{ab}$ \\
\hline CaCl2 (1\%) & 45.61 & 45.57 & 45.12 & 44.97 & 44.41 & 43.87 & 43.30 & 42.68 & 41.93 & $41.47 \mathrm{a}$ \\
\hline Bavistin (0.1\%) & 46.69 & 45.65 & 45.23 & 44.56 & 44.49 & 43.62 & 42.72 & 42.68 & 42.45 & $41.86 \mathrm{a}$ \\
\hline Wax (10\%) & 48.22 & 47.79 & 47.09 & 45.09 & 45.34 & 44.33 & 43.30 & 43.16 & 42.89 & $42.04 \mathrm{a}$ \\
\hline $\begin{array}{l}\text { Wax }(10 \%) \\
\text { Bavistin }(0.1 \%)\end{array}$ & 48.23 & 47.07 & 46.37 & 46.05 & 45.62 & 45.00 & 44.66 & 44.35 & 44.27 & $43.72 \mathrm{a}$ \\
\hline SEm $( \pm)$ & 1.731 & 1.933 & 1.855 & 1.282 & 2.044 & 1.133 & 1.565 & 1.807 & 1.869 & 2.173 \\
\hline LSD $(=0.05)$ & $\mathrm{ns}$ & $\mathrm{ns}$ & $\mathrm{ns}$ & $\mathrm{ns}$ & $\mathrm{ns}$ & $\mathrm{Ns}$ & $\mathrm{ns}$ & $\mathrm{ns}$ & $\mathrm{ns}$ & 6.390 \\
\hline CV, \% & 7.3 & 8.3 & 8.1 & 5.7 & 9.1 & 5.1 & 7.2 & 8.5 & 9.1 & 10.9 \\
\hline P-value & 0.896 & 0.961 & 0.897 & 0.759 & 0.991 & 0.550 & 0.653 & 0.534 & 0.225 & 0.048 \\
\hline Grand mean & 47.20 & 46.59 & 46.06 & 45.21 & 44.83 & 44.06 & 43.18 & 42.71 & 41.25 & 39.69 \\
\hline
\end{tabular}

LSD $=$ Least Significant Difference, SEM = Standard Error of Mean, and CV = Coefficient of variation, ns = nonsignificant

\section{Total soluble solutes (TSS)}

TSS content is one of the major indicators that determine the quality of mandarin orange. As shown in Table 3, TSS content increased with the increasing period of storage in all the treatments and the increasing trend is higher in untreated (control), Eucalyptus and calcium chloride treated fruits than the fruits treated with other coatings. Fruits treated with calcium chloride showed the maximum TSS content during the storage 
period and ranged from $12.30^{\circ}$ brix during $3 \mathrm{rd}$ day to $15.45^{\circ}$ brix during 41 st day which was statistically at par with untreated fruits \& Eucalyptus treated fruits and minimum TSS content was recorded in the fruits treated with $10 \%$ wax from $3 \mathrm{rd}$ day of storage $\left(11.83^{\circ} \mathrm{brix}\right)$ to 41 st day of storage $\left(13.35^{\circ}\right.$ brix $)$ which was statistically at par with wax $10 \%$ in combination with Bavistin $0.1 \%$ from 3 rd day to 41 st day of storage. The trend showed that wax treated fruits was significantly superior because of the gradual increment in the TSS change whereas in calcium chloride treated and control it was increased at a faster pace. The faster rate in the TSS increment in the calcium chloride treated and untreated fruits were might be due to faster metabolic activities through respiration and transpiration than in the other coatings (Akhtar et al., 2010). (Rokaya, 2017) reported that untreated (control) fruits showed the maximum TSS content during the storage and ranged from the 1st week $\left(10.92^{\circ}\right.$ Brix) to the 4 th week $\left(12.88^{\circ}\right.$ Brix $)$ and minimum TSS was recorded in the fruits treated with wax $10 \%$ from the 1 st week $\left(10.35^{\circ}\right.$ Brix $)$ to the 4 th week $\left(11.51^{\circ}\right.$ Brix $)$ which was at par with wax $10 \%$ in combination with Bavistin 0.1\% from the 1st week $\left(10.39^{\circ}\right.$ Brix $)$ to the 4 th week $\left(11.65^{\circ}\right.$ Brix $)$. Similarly, the results are in line with the results of Bisen et al. (2012) in Kagzi lime; Waskar \& Gaikwad (2005) in Keshar mango; Jholgiker \& Reddy (2007) in Sugar apple (Annona squamosa L.) fruits, Shahid \& Abbasi (2011) in sweet orange, Hassan et al. (2014) in tangerine citrus.

\begin{tabular}{|c|c|c|c|c|c|c|c|c|c|c|}
\hline \multirow[t]{2}{*}{ Treatments } & \multicolumn{10}{|c|}{ TSS of fruits on days indicated } \\
\hline & Day 3 & Day 6 & Day 9 & Day 12 & Day 15 & Day 18 & Day 21 & Day 24 & Day 27 & Day 41 \\
\hline Control & 11.85 & 12.23 & 12.55 & 13.00 & 13.18 & 13.70 & 13.93 & $14.23^{\mathrm{a}}$ & $14.25^{\mathrm{a}}$ & $15.35^{\mathrm{a}}$ \\
\hline Cinnamon Oil (2\%) & 11.80 & 11.83 & 12.60 & 12.75 & 12.85 & 13.50 & 13.53 & $13.60^{\mathrm{abc}}$ & $13.63^{\mathrm{ab}}$ & $14.05^{\mathrm{bc}}$ \\
\hline Eucalyptus oil (2\%) & 12.50 & 12.65 & 12.90 & 13.03 & 13.08 & 13.50 & 13.62 & $13.63^{\mathrm{abc}}$ & $13.65^{\mathrm{ab}}$ & $14.53^{\mathrm{ab}}$ \\
\hline $\mathrm{CaCl} 2(1 \%)$ & 12.30 & 12.38 & 13.28 & 13.30 & 13.33 & 13.60 & 13.68 & $14.03^{\mathrm{a}}$ & $14.13^{\mathrm{a}}$ & $15.45^{\mathrm{a}}$ \\
\hline Bavistin $(0.1 \%)$ & 12.00 & 12.20 & 12.63 & 12.73 & 12.88 & 13.70 & 13.73 & $13.90^{\mathrm{ab}}$ & $13.95^{\mathrm{a}}$ & $14.60^{\mathrm{ab}}$ \\
\hline Wax $(10 \%)$ & 11.83 & 11.95 & 12.10 & 12.30 & 12.40 & 12.65 & 12.78 & $13.03^{\mathrm{bc}}$ & $13.10^{\mathrm{b}}$ & $13.35^{\mathrm{c}}$ \\
\hline $\begin{array}{|ll|}\text { Wax } \quad(10 \%) & + \\
\text { Bavistin }(0.1 \%) & \\
\end{array}$ & 11.93 & 12.00 & 12.33 & 12.50 & 12.68 & 12.83 & 12.90 & $13.00^{\mathrm{c}}$ & $13.08^{b}$ & $13.12^{\mathrm{c}}$ \\
\hline $\operatorname{Sem}( \pm)$ & 0.663 & 0.389 & 0.370 & 0.318 & 0.286 & 0.390 & 0.416 & 0.276 & 0.251 & 0.347 \\
\hline $\operatorname{LSD}(=0.05)$ & ns & ns & ns & ns & $\mathrm{ns}$ & Ns & ns & 0.811 & 0.738 & 1.021 \\
\hline $\mathrm{CV}, \%$ & 11.0 & 6.4 & 5.9 & 5.0 & 4.4 & 5.8 & 6.2 & 4.0 & 3.7 & 4.8 \\
\hline P-value & 0.984 & 0787 & 0.417 & 0.376 & 0.342 & 0.332 & 0.394 & 0.030 & 0.016 & $<0.001$ \\
\hline Grand mean & 12.03 & 12.18 & 12.63 & 12.80 & 12.91 & 13.35 & 13.45 & 13.63 & 13.68 & 14.35 \\
\hline
\end{tabular}

LSD $=$ Least Significant Difference, SEM $=$ Standard Error of Mean, and CV = Coefficient of variation, $\mathrm{ns}=$ nonsignificant

\section{Titrable Acidity}

As data presented in Table 4 titratable acidity of different treatments was significant at the end of the storage period. The TA was significantly decreased with the advancement of the storage period. Higher acidity was recorded in the fruits treated with wax $10 \%$ along with Bavistin $0.1 \%$ which was 0.68 at 3rd day of storage and 0.55 on 41 th day of storage period whereas there was a significant decrease in the TA content of the fruits left untreated which was 0.66 on 3rd day of storage and 0.40 on 41 st day of storage period. The decreasing trend of titratable acidity during the storage period was probably due to the utilization of acid in the tricarboxylic acid cycle in the respiration process (Rokaya, 2017). The higher acidity in wax treated fruits was might be due to less utilization of the acids in the respiration process during the storage whereas untreated fruits with minimum acids was due to faster utilization of the acids in the respiration process during storage (Bisen et al. 2012). Rokaya (2017) recorded maximum TA in the fruits treated with wax $10 \%$ plus Bavistin $0.1 \%$ against control at the end of the storage. Similarly, the results are in line with, Ahmad et al. (2013) in Kinnow fruit, Hassan et al. (2014) tangerine citrus var. Siam Banjar. 
Table 4: Effect of postharvest treatments on titratable acidity (TA) of mandarin fruit during storage at ambient condition (12.42 $\pm 0.280 \mathrm{C}$ mean temperature, $68.56 \pm 1.46 \% \mathrm{RH})$, Udayapur, Nepal, (2017-18)

\begin{tabular}{|l|l|l|l|l|l|l|l|l|l|l|}
\hline \multirow{2}{*}{ Treatments } & \multicolumn{10}{|l|}{ Titrable acidity on days indicated (\%) } \\
\cline { 2 - 13 } & Day 3 & Day 6 & Day 9 & Day 12 & Day 15 & Day 18 & Day 21 & Day 24 & Day 27 & Day 41 \\
\hline Control & 0.66 & 0.63 & 0.61 & 0.60 & 0.57 & 0.54 & 0.50 & 0.47 & $0.42 \mathrm{~b}$ & $0.40 \mathrm{c}$ \\
\hline Cinnamon Oil (2\%) & 0.68 & 0.67 & 0.65 & 0.64 & 0.62 & 0.60 & 0.59 & 0.58 & $0.51 \mathrm{a}$ & $0.48 \mathrm{abc}$ \\
\hline Eucalyptus oil (2\%) & 0.68 & 0.67 & 0.63 & 0.62 & 0.60 & 0.58 & 0.56 & 0.54 & $0.53 \mathrm{a}$ & $0.50 \mathrm{abc}$ \\
\hline CaCl2 (1\%) & 0.67 & 0.64 & 0.61 & 0.58 & 0.56 & 0.55 & 0.52 & 0.50 & $0.49 \mathrm{ab}$ & $0.47 \mathrm{abc}$ \\
\hline Bavistin (0.1\%) & 0.67 & 0.66 & 0.64 & 0.58 & 0.56 & 0.54 & 0.51 & 0.49 & $0.46 \mathrm{ab}$ & $0.43 \mathrm{bc}$ \\
\hline Wax (10\%) & 0.69 & 0.66 & 0.64 & 0.62 & 0.60 & 0.59 & 0.56 & 0.55 & $0.54 \mathrm{a}$ & $0.52 \mathrm{ab}$ \\
\hline $\begin{array}{l}\text { Wax (10\%) } \\
\text { Bavistin }(0.1 \%)\end{array}$ & 0.68 & 0.66 & 0.64 & 0.63 & 0.62 & 0.60 & 0.58 & 0.57 & $0.56 \mathrm{a}$ & $0.55 \mathrm{a}$ \\
\hline Sem $( \pm)$ & 0.0303 & 0.0543 & 0.0431 & 0.0280 & 0.0382 & 0.0357 & 0.0653 & 0.0343 & 0.0290 & 0.0330 \\
\hline LSD (=0.05) & $\mathrm{ns}$ & $\mathrm{Ns}$ & $\mathrm{ns}$ & $\mathrm{ns}$ & $\mathrm{ns}$ & $\mathrm{Ns}$ & $\mathrm{ns}$ & $\mathrm{ns}$ & 0.0852 & 0.0970 \\
\hline CV, \% & 9.0 & 16.6 & 13.6 & 9.2 & 13.0 & 12.5 & 24.0 & 13.0 & 11.5 & 13.8 \\
\hline P-value & 0.989 & 0.998 & 0.989 & 0.683 & 0.827 & 0.724 & 0.929 & 0.199 & 0.030 & 0.067 \\
\hline Grand mean & 0.68 & 0.66 & 0.63 & 0.61 & 0.59 & 0.57 & 0.54 & 0.53 & 0.50 & 0.48 \\
\hline
\end{tabular}

LSD $=$ Least Significant Difference, SEM $=$ Standard Error of Mean, and CV $=$ Coefficient of variation, $\mathrm{ns}=$ nonsignificant

\section{TSS/TA Ratio}

TSS/TA ratio of mandarin fruit as influenced by a different combination of treatments is depicted in Table 5. At the beginning of the storage period from 3 rd day to 21 st day no significant differences were observed among the treatments. From 24th day to
41 st day of storage significant differences among the treatments were observed. On the41st day of storage, the significantly maximum ratio was observed with untreated fruits (38.06) while the minimum ratio was observed with wax $10 \%$ in combination with Bavistin $0.1 \%$ (24.73).

Table 5: Effect of postharvest treatments on TSS/TA ratio of mandarin fruit during storage at ambient condition (12.42 $\pm 0.280 \mathrm{C}$ mean temperature, $68.56 \pm 1.46 \% \mathrm{RH})$, Udayapur, Nepal, (2017-18)

\begin{tabular}{|l|l|l|l|l|l|l|l|l|l|l|}
\hline \multirow{2}{*}{ Treatments } & \multicolumn{10}{|l|}{ TSS/TA on days indicated } \\
\cline { 2 - 12 } & Day 3 & Day 6 & Day 9 & Day 12 & Day 15 & Day 18 & Day 21 & Day 24 & Day 27 & Day 41 \\
\hline Control & 17.78 & 19.44 & 20.68 & 22.00 & 23.46 & 25.72 & 28.36 & $30.68 \mathrm{a}$ & $34.35 \mathrm{a}$ & $38.06 \mathrm{a}$ \\
\hline Cinnamon Oil (2\%) & 17.37 & 18.13 & 19.66 & 19.93 & 20.88 & 22.96 & 23.08 & $23.38 \mathrm{~b}$ & $27.26 \mathrm{bc}$ & $30.17 \mathrm{bc}$ \\
\hline Eucalyptus oil (2\%) & 18.78 & 19.12 & 20.49 & 21.20 & 22.32 & 23.48 & 26.14 & $25.78 \mathrm{ab}$ & $25.89 \mathrm{a}$ & $29.01 \mathrm{bcd}$ \\
\hline CaCl2 (1\%) & 18.40 & 19.39 & 21.97 & 22.90 & 24.33 & 24.88 & 26.42 & $27.85 \mathrm{ab}$ & $29.28 \mathrm{abc}$ & $33.44 \mathrm{ab}$ \\
\hline Bavistin (0.1\%) & 18.07 & 18.80 & 20.04 & 21.92 & 23.24 & 25.93 & 28.68 & $28.99 \mathrm{ab}$ & $30.30 \mathrm{ab}$ & $34.00 \mathrm{ab}$ \\
\hline Wax (10\%) & 17.17 & 18.91 & 19.51 & 19.80 & 21.00 & 21.79 & 24.90 & $24.45 \mathrm{~b}$ & $24.40 \mathrm{bc}$ & $25.90 \mathrm{~cd}$ \\
\hline $\begin{array}{l}\text { Wax (10\%) } \\
\text { Bavistin }(0.1 \%)\end{array}$ & 17.68 & 18.31 & 19.33 & 19.89 & 20.55 & 21.56 & 22.69 & $23.35 \mathrm{~b}$ & $23.47 \mathrm{c}$ & $24.73 \mathrm{~d}$ \\
\hline SEm $( \pm)$ & 1.098 & 1.303 & 1.360 & 1.068 & 1.476 & 1.484 & 2.67 & 1.901 & 1.939 & 1.673 \\
\hline LSD $(=0.05)$ & $\mathrm{ns}$ & $\mathrm{ns}$ & $\mathrm{ns}$ & $\mathrm{ns}$ & $\mathrm{ns}$ & $\mathrm{Ns}$ & $\mathrm{ns}$ & 5.590 & 5.702 & 4.921 \\
\hline CV, \% & 12.3 & 13.8 & 13.4 & 10.1 & 13.3 & 12.5 & 20.7 & 14.4 & 13.9 & 10.9 \\
\hline P-value & 0.946 & 0.987 & 0.838 & 0.279 & 0.450 & 0.241 & 0.598 & 0.073 & $<0.001$ & $<0.001$ \\
\hline Grand mean & 17.89 & 18.87 & 20.24 & 21.09 & 22.25 & 23.76 & 25.75 & 26.35 & 27.85 & 30.76 \\
\hline
\end{tabular}

LSD $=$ Least Significant Difference, $\mathrm{SEM}=$ Standard Error of Mean, and CV $=$ Coefficient of variation, $\mathrm{ns}=$ nonsignificant 


\section{pH of the fruit}

None of the treatment had any significant effects on $\mathrm{pH}$ of fruits as shown in table 6.Fruits that were untreated showed maximum (3.73 to 4.48$) \mathrm{pH}$ followed by Calcium chloride (1\%) (4.05 to 4.43$)$ which were statistically at par with Bavistin $(0.1 \%)$ treated fruits (4.05 to 4.43 ) up to 41 days of storage. When the storage period was increased, the $\mathrm{pH}$ value of Mandarin fruits was also increased gradually under all the treatments. It may be due to the conversion and utilization of different acids in the respiration process (Rokaya, 2017). While the minimum $\mathrm{pH}$ value was retained by the fruits those were coated with paraffin wax $10 \%$ in combination with Bavistin 0.1\% which might be due to the slower process of respiration and utilization of organic acids present in mandarin fruits which were statistically at par with cinnamon oil $2 \%$ treated fruits.

Table 6: Effect of postharvest treatments on $\mathrm{pH}$ of mandarin fruit during storage at ambient condition $(12.42 \pm 0.280 \mathrm{C}$ mean temperature, $68.56 \pm 1.46 \% \mathrm{RH})$, Udayapur, Nepal, (2017-18)

\begin{tabular}{|l|l|l|l|l|l|l|l|l|l|l|}
\hline \multirow{2}{*}{ Treatments } & \multicolumn{9}{|l|}{ pH of fruit juice on days indicated } \\
\cline { 2 - 13 } & Day 3 & Day 6 & Day 9 & Day 12 & Day 15 & Day 18 & Day 21 & Day 24 & Day 27 & Day 41 \\
\hline Control & $3.73 \mathrm{~b}$ & 3.88 & 3.95 & 4.13 & 4.15 & 4.23 & 4.35 & 4.38 & 4.43 & 4.48 \\
\hline Cinnamon Oil (2\%) & $3.98 \mathrm{a}$ & 4.08 & 4.10 & 4.10 & 4.10 & 4.18 & 4.18 & 4.28 & 4.38 & 4.10 \\
\hline Eucalyptus oil (2\%) & $3.93 \mathrm{ab}$ & 3.98 & 4.20 & 4.20 & 4.25 & 4.25 & 4.30 & 4.35 & 4.38 & 4.38 \\
\hline CaCl2 (1\%) & $4.05 \mathrm{a}$ & 4.10 & 4.13 & 4.15 & 4.20 & 4.23 & 4.25 & 4.35 & 4.40 & 4.43 \\
\hline Bavistin (0.1\%) & $4.05 \mathrm{a}$ & 4.08 & 4.13 & 4.20 & 4.23 & 4.23 & 4.28 & 4.30 & 4.40 & 4.43 \\
\hline Wax (10\%) & $4.13 \mathrm{a}$ & 4.13 & 4.15 & 4.23 & 4.25 & 4.25 & 4.25 & 4.28 & 4.28 & 4.30 \\
\hline $\begin{array}{l}\text { Wax (10\%) } \\
\text { Bavistin }(0.1 \%)\end{array}$ & $3.90 \mathrm{ab}$ & 4.00 & 4.10 & 4.10 & 4.13 & 4.13 & 4.13 & 4.13 & 4.18 & 4.18 \\
\hline SEm $( \pm)$ & & & & & & & & & & \\
\hline LSD $(=0.05)$ & 0.0748 & 0.0815 & 0.1173 & 0.1795 & 0.1356 & 0.997 & 0.959 & 0.940 & 0.899 & 0.1654 \\
\hline CV, \% & 0.2200 & ns & ns & ns & ns & ns & ns & ns & ns & ns \\
\hline P-value & 3.8 & 4.0 & 5.7 & 8.6 & 6.5 & 7.2 & 7.3 & 7.4 & 6.9 & 7.6 \\
\hline Grand mean & 0.025 & 0.368 & 0.847 & 0.997 & 0.972 & 0.997 & 0.959 & 0.940 & 0.899 & 0.635 \\
\hline
\end{tabular}

LSD $=$ Least Significant Difference, SEM = Standard Error of Mean, and CV = Coefficient of variation, $n s=$ nonsignificant

\section{Postharvest life}

Fruits treated with Wax (10\%) and Bavistin $(0.1 \%)$ showed maximum postharvest life of 73 days followed by Wax $(10 \%)$. Similarly, minimum span was recorded in control fruits (46days) followed by Eucalyptus oil (2\%) (51 days) which is shown in the diagram below.

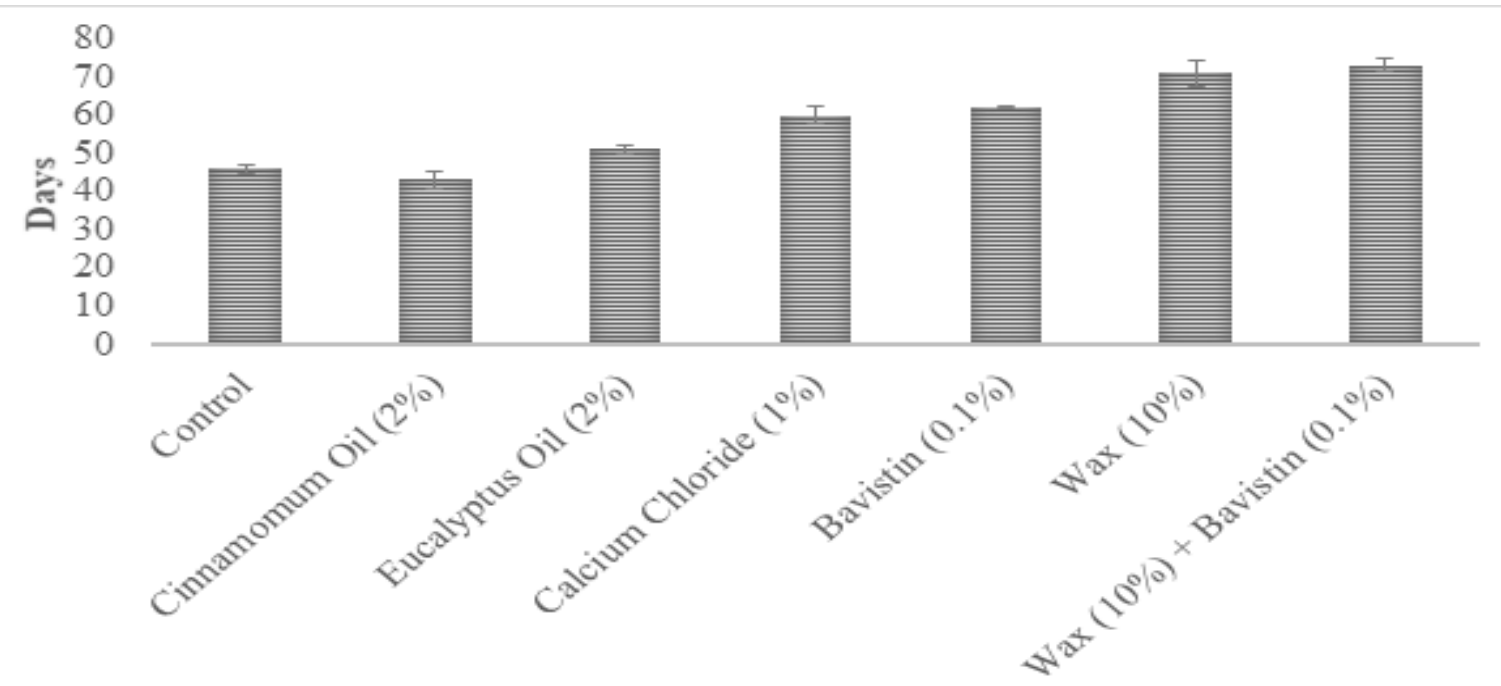

Treatments

Figure 1: The Postharvest life of different treatments under ambient room condition 


\section{Conclusion}

Prolongation of shelf life, as well as the quality of mandarin fruit, could be retained with the use of different surface coatings than without using them. Paraffin wax coating prolonged the storability of mandarin fruits up to 73 days without adversely affecting their physicochemical and chemical parameters. Hence, coating of mandarin fruits with paraffin wax may be useful for expending their shelf life and effective in stabilizing the market demand. (Even if we used Bavistin in the surface of the fruit and at low concentration as positive control (for experimental purpose), sometimes its use may be harmful if used haphazardly, so we should avoid using such chemicals in real life scenario).

\section{References}

Ahmad, S., Thakur, K., \& Siddiqui, M. W. (2013). Postharvest treatments for preserving quality of 'kinnow' fruit under different storage conditions. Advances in Horticultural Science, 1-6.

Akhtar, A., Abbasi, N. A., \& Hussain, A. (2010). Effect of calcium chloride treatments on quality characteristics of loquat fruit during storage. Pakistani Journal of Botany, 181-188.

Bhattarai, R. R., Rijal, R. K., \& Mishra, P. (2013). Postharvest losses in mandarin orange:A case study of Dhankuta District Nepal. African Journal of Agricultural Research, 763-767.

Bisen, A., Pandey, S., \& Patel, N. (2012). Effect of skin coatings on prolonging shelflife of kagzi lime fruits(Citrus aurantifolia swingle). Journal of Food Science and Technology, 753-759.

FAO. (2016, June 3). Statistical Year Book. Retrieved from Food and Agriculture Report: http://www. faostat.fao.org/site/339/default.aspx

Hassan, Z., Lesmayati, S., Qomariah, R., \& Hasbianto, A. (2014). Effects of wax coating application and storage temperatures on the on the quality of tangerine citrus (Citrus reticulata) var.Siam Banjar. International Food Research Journal, 641-648.

Jholgiker, P., \& Reddy, B. (2007). Effect of different surface coating material on postharvest physiology of (Annona squamosa L.) fruits under ambient and zero energy cool chamber storage. . Indian Journal of Horticulture, 64(1), 41-44.
Kader, A. (2005). Increasing food availability and reducing postharvest losses of fresh produce. In Proceeding of 5th International postharvest symposium. F.Mencarelli \& P. Tonutti,Acta Horticulture.

Mahajan, B., Dhatt, A., \& Sandhu, K. (2005). Effect of different postharvest treatments on the storage life of kinnow. Journal of Food Science and Technology ,(Mysore) 42.4: , 296-299.

Mahajan, B., Dhillon, W., \& Kumar, M. (2013). Effect of surface coatings on the shelflife and quality of kinnow fruits during storage. Journal of Postharvest Technology, 008-015.

MoAD. (2016). Statistical Information and Nepalese Agriculture. Singhdurbar, Kathmandu,Nepal: Agri Statistics Section,Agribusiness Promotion and Statistics Division,Ministry of Agriculture Development.

Parashar, M. (2009). Post'-harvest profile of mandarin. Government of India, Ministry of Agriculture, (Department of Agriculture \& Cooperation), Directorate of Marketing \& Inspection, Branch Head Office Nagpur.Nagpur,India.pp100.

Rokaya, P. R. (2017, December). Effect of altitude and various pre and postharvest factors on quality and shelflife of mandarin (Citrus reticulata,Blanco) (Ph.D. thesis). Agriculture And Forestry University,Rampur,Chitwan,Nepal.

Sahu, B. (2016, July). Effect of different postharvest treatments on prolonging shelflife of sugar apple(Annona squamosa L.)(M.Sc. Thesis). Indira gandhi Krishi Vishwavidyalya,India.

Shahid, M., \& Abbasi, N. (2011). Effect of bee wax coatings on physiological changes in fruits of sweet orange cv. "Blood Red". Sarhad Journal of Agriculture.27(3), 385-394.

Statistical Year Book. (2015/16). Government of Nepal, National Planning Comission, Central Bureau of Statistics, Thapathali, Kathmandu, Nepal.

Waskar, D., \& Gaikwad, R. (2005). Effect of various postharvest treatments on extension of shelflife of keshar mango fruits. Indian Journal of Agriculture Research, 95-102. 